\title{
Risk Measures and Dynamical Systems ${ }^{\#}$
}

\author{
Karel Vaníček
}

\section{Introduction}

Generally speaking, measuring market risk has become one of the substantial and primary activities in the world of finance since early nineties of the last century. Dozens of research studies and technical documents have been dedicated to the concepts, which are able to quantify and predict market risk. Many of financial institutions, even in the Czech Republic, use their own internally developed models for measuring market risk. The accuracy and appropriateness of such models are essential and so are the underlying methodologies. Such models are usually put in practice and used for estimation of future movements of stock prices, share indexes, exchange rates, precious metal prices etc.

The most popular techniques for quantification market risk are by no means the quantile based risk measures. VaR (Value at Risk), as one of the widely known, has been using for a long time and is often implemented in the internally developed models. Some of the advantages of VaR can be described as: it has clear meaning, it can be easy estimated and measured. On the other hand VaR is not a "coherent" risk measure and lacks of subadditivity condition; see for instance Vaníček K. (2003). ES (Expected Shortfall) or sometimes called $\mathrm{CVaR}$ (Conditional $\mathrm{VaR}$ ) is another quantile based which does not have such drawbacks as VaR and can be classified as coherent risk measure. Both of the mentioned measures are worth estimating and we will derive explicit formula for their evaluation in our study.

In our paper we would like to introduce methodology that combines results from the popular time series analysis and from the theory of heavy tailed distributions. Financial time series can be analyzed in many ways, but some of the techniques are not able to capture the dynamic stochastic behavior of market changes as some other are. Concerning our study, we combine the so called GARCH (Generalized Autoregressive Conditional Heteroscedastic) models and EVT (Extreme Value Theory) models. The combinations of both of the mentioned methodologies were introduced quite recently in McNeil (1998) or in McNeil and Frey (2000).

\section{Underlying methodologies}

\section{ARMA (p, q)-GARCH (r, s) models in practice}

If we look back in time, we can observe very significant evolution of assumptions taken into account in the studies devoted to analysis of market share prices. Firstly, it was generally assumed that market prices are time independent and do not follow any dependence pattern. Obviously this was in odds with real behavior of most of share prices

\# The research was supported by the Czech Science Foundation under Grant 402/03/H057.

* Mgr. Karel Vaníček - student of doctoral study; Department of Probability and Mathematical Statistics, Faculty of Mathematics and Physics, Charles University in Prague, Ke Karlovu 3, 12116 Prague 2; <karel.vanicek@cnb.cz>. 
or indexes. That is why many of the recent studies suggested incorporating more complex models, because there is strong empirical evidence that most of the historical time series of market prices do have time varying trend and volatility. The popular theory that can describe interdependences among volatility, trend and past observations of time series is generally called ARMA-GARCH type model.

Let $\left(Z_{t}, t \in N\right)$ be a strictly stationary time series representing in our paper daily observation of the negative log return on an underlying financial instrument. Let $S_{t-1}$ and $\mathrm{S}_{t}$ denote the closing prices of underlying asset on day $\mathrm{t}-1$ and $\mathrm{t}$.

$$
Z_{t}=-\left(\log S_{t}-\log S_{t-1}\right) \approx \frac{S_{t-1}-S_{t}}{S_{t-1}} .
$$

Let assume that the time dynamics of losses is described by the following formula:

$$
Z_{t}=\mu_{t}+\sigma_{t} \cdot X_{t}
$$

where $\sigma_{\mathrm{t}}$ and $\mu_{\mathrm{t}}$ is volatility of the loss and the expected loss on day $\mathrm{t}$ respectively. $X_{\mathrm{t}}$ stands for process of innovations, which are independent and identically distributed with constant zero mean, constant unit variance and cumulative distribution function $F(x)$. The first two variables are considered to depend on the past historical losses, which can be described by ARMA-GARCH family of models. The ARMA part describes the dynamics of the trend (expected loss, conditional mean) and the GARCH part reflects the stochastic behavior of the conditional volatility of losses. One of the simplest examples can be AR (1)-GARCH $(1,1)$, which takes the following form:

$$
\begin{aligned}
& \mu_{t}=\lambda \cdot Z_{t-1}, \\
& \sigma_{t}^{2}=\alpha_{0}+\alpha_{1} \cdot\left(Z_{t-1}-\mu_{t-1}\right)^{2}+\beta \cdot \sigma_{t-1}^{2}, \\
& \alpha_{0}, \alpha_{1}, \beta>0 ; \alpha_{1}+\beta<1 ;|\lambda|<1 .
\end{aligned}
$$

The above proposed model can be easily extended to more complex models, but for illustration is sufficient. The limiting conditions for all parameters ensure that our considered time series of losses is strictly stationary.

The unknown parameters can be possibly obtained by the standard ML (Maximum likelihood) techniques. But, as will be discussed later, we will not believe that the innovations of the GARCH model are normally distributed. Such obstacle can be overridden by so called PML (Pseudo-Maximum-Likelihood) approach. The PML method gives us reasonable parameter estimates $\left(\hat{\lambda}, \hat{\alpha}_{0}, \hat{\alpha}_{1}, \hat{\beta}\right)$, which are consistent and asymptotically normal estimators.

\section{Extreme Value Theory (EVT)}

The basic motivation for the use of EVT instead of standard techniques, which assume the normality conditions, is simply the fact that the innovations in the model (2) are not normally distributed. This statement can be verified if we compare estimated residuals from the fitted ARMA-GARCH model:

$$
x_{i}=\frac{z_{i}-\hat{\mu}_{i}}{\hat{\sigma}_{i}}, i=1, \ldots, t
$$


with the normal distribution using for example qq-plots or a Kolmogorov-Smirnov test. Forming the qq-plot it would become obvious that the assumption of conditional normality is unrealistic and that the innovation process has fat tails.

EVT is basically the statistical methodology concerning limiting distributions of extreme values (minima, maxima, upper order statistics, ...). One of the particular methods of EVT is the POT (Peaks Over Threshold) method, which is able to describe and estimate far tails of distribution, in our case the distribution of losses of underlying asset. In practice, it is reasonable and appropriate to estimate quantiles at high level of confidence e.g. at 99\%, $99.5 \%$ or $99.9 \%$ and this may be quite difficult, because of a lack of data at far ends of the distribution. We would like to estimate quantile risk measures at a high confidence level and we can do it, using the EVT-POT method.

If we analyze our problem in more details, we can arrive with the question: How does the distribution of excesses over some high threshold level $u$ look like? Typically $u$ is set to $90 \%$ or $95 \%$-emprical quantile. Mathematically written, we are looking for the following:

$$
F_{u}(y)=P(X-u \leq y \mid X>u)=\frac{F(y+u)-F(u)}{1-F(u)}, 0<\mathrm{y}<x_{F}-u
$$

where $x_{F}$ is (finite or infinite) right endpoint of the distribution $F(x)$. The approximation of the distribution of excesses can be done using Pickands-Balkema theorem, for more details consult Embrechts, Klüppelberg and Mikosch T. (1997). It can be proved that for a large class of underlying distribution functions $F(x)$ and some positive measurable function $\beta(\cdot)$ the following is true:

$$
\lim _{u \rightarrow x_{F}} \sup _{0 \leq y<x_{F}-u}\left|F_{u}(y)-G_{\xi, \beta(u)}(y)\right|=0,
$$

If we fix the threshold level $u$ at some predefined value, we obtain the GPD (Generalized Pareto Distribution) as a good approximation of the cumulative distribution function over threshold level. The threshold value must be sufficiently high to satisfy limiting criteria, but on the other hand there must be left enough data for parameter estimation procedure. Then the GPD has the distribution function of the closed form:

$$
\begin{aligned}
G_{\xi, \beta(u)}(y) & =1-\left(1-\frac{\xi \cdot y}{\beta}\right)^{-1 / \xi} & , \xi \neq 0 \\
& =1-\exp \left(-\frac{y}{\beta}\right) & , \xi=0 .
\end{aligned}
$$

The preceding results will be crucial for estimation the right tail of original distribution of losses. We fit the GPD to the $N$ excesses over threshold $u$ using again ML method. We arrive with the necessary estimates $(\hat{\xi}, \hat{\beta})$ of the parameters $(\xi, \beta)$.

After some elementary algebraic operations, it turns out that we can express the equation (5) of the underlying distribution of losses as:

$$
F(x)=1-\left((1-F(u)) \cdot\left(1-F_{u}(x-u)\right)\right), x>u .
$$

According to our assumptions, we have totally $t$ independent observations of the random variable $X$. Let denote by $N$ the number of observations that are higher than the threshold level $u$. The reasonable estimators in equation (8) can be taken as: 


$$
\begin{aligned}
& \hat{F}(u)=P(X \leq u)=\frac{t-N}{t}, \\
& \hat{F}_{u}(x-u)=G_{\xi, \beta}(x-u), x>u .
\end{aligned}
$$

Finally putting the estimates from (9) to (8), we obtain the tail estimator:

$$
\hat{F}(x)=1-\frac{N}{t} \cdot\left(1+\hat{\xi} \cdot \frac{x-u}{\hat{\beta}}\right)^{-1 / \hat{\xi}}, x>u,
$$

which will be essential for estimating both the VaR and the ES risk measures.

Other useful probabilistic properties of the GPD can be summarized in the following statement. Let suppose that $X$ has the GPD with parameters $\xi>1$ and $\beta$. Then for every $u<x_{F}$ holds:

$$
\begin{aligned}
& e(u)=E(X-u \mid X>u)=\frac{\beta+\xi \cdot u}{1-\xi}, \beta+u \cdot \xi>0 \\
& X-V a R_{\alpha} \mid X>V a R_{\alpha} \sim G P D_{\xi, \beta+\xi \cdot\left(\operatorname{VaR}_{\alpha}-u\right)} \Rightarrow \\
& \Rightarrow E\left(X \mid X>V_{a} R_{\alpha}\right)=\frac{V a R_{\alpha}+\beta-\xi \cdot u}{1-\xi}, \quad V_{a}>u .
\end{aligned}
$$

\section{VaR and ES}

The estimation and computation of quantile based risk measures simply means reverting or modifying inverse of the distribution function. Let $F(x)$ denote the marginal distribution of $\left(X_{t}\right)$. To make the statement clear and complete, we define the unconditional $\alpha$-quantile of $F(x)$ as follows:

$$
\operatorname{VaR}_{\alpha}=\inf \{x \in \mathfrak{R} F(x) \geq \alpha\}=F^{-1}(\alpha), \quad 0<\alpha<1 .
$$

The alternative risk measure ES, tells us how big our losses will be on average, if the losses are above some quantile level, typically above the $\mathrm{VaR}_{\alpha}$. The unconditional expected shortfall is defined:

$$
E S_{\alpha}=E\left(X \mid X>\operatorname{VaR}_{\alpha}\right)=\operatorname{VaR}_{\alpha}+E\left(X-\operatorname{VaR}_{\alpha} \mid X>\operatorname{VaR}_{\alpha}\right), \quad 0<\alpha<1 .
$$

\section{Dynamic risk measures}

Why don't we add all the theoretical parts from the previous sections into one particular model? If we follow the idea that not only market losses behave according to ARMA-GARCH stochastic model but also risk measures $\mathrm{VaR}_{\alpha}, E S_{\alpha}$ do, we can derive the stochastic equation for the dynamic risk measures:

$$
\begin{aligned}
& \operatorname{VaR}_{\alpha}^{t+1}\left(Z_{t+1}\right)=\mu_{t+1}+\sigma_{t+1} \cdot \operatorname{VaR}_{\alpha}(X), \\
& \operatorname{ES}_{\alpha}^{t+1}\left(Z_{t+1}\right)=\mu_{t+1}+\sigma_{t+1} \cdot E S_{\alpha}(X) .
\end{aligned}
$$

Taking into account such model, we need to estimate 1-step forecast for unobserved volatility and expected loss based on historical observations till the time $t$. Estimators for 
unknown parameters in the ARMA-GARCH models can be obtained by PML method and after that we can arrive with forecasts of volatility and expected loss. Also model residuals have to be computed using again estimated parameters, see equation (4).

Now we apply EVT theory to the residuals and estimate parameters for the GPD. If we inverse equation (10) we obtain the direct expression for the first risk measure:

$$
\operatorname{VaR}_{\alpha}(X)=u+\frac{\hat{\beta}}{\hat{\xi}}\left(\left(\frac{t}{N} \cdot(1-\alpha)^{-\hat{\xi}}-1\right), \quad \alpha>F(u) .\right.
$$

The second risk measure can be directly obtained using equation (11) and estimated parameters of the GPD. Both of the parts form the following expression:

$$
E S_{\alpha}(X)=E\left(X \mid X>\operatorname{VaR}_{\alpha}(X)\right) \frac{\operatorname{VaR}_{\alpha}(X)+\hat{\beta}-\hat{\xi} \cdot u}{1-\hat{\xi}}, \quad \operatorname{VaR}_{\alpha}>u
$$

Let summarized the previous procedures into two stage algorithm that gives us required results:

1. An ARMA-GARCH stochastic volatility model is fitted to the historical data of losses connected with underlying asset. From this model residuals are extracted. The ARMA-GARCH model is used to calculate 1-step predictions of $\mu_{t+1}, \sigma_{t+1}$.

2. EVT is applied to the residuals. For some reasonable choice of the threshold level $u$ the POT method is used to estimate both static risk measures. The final dynamic risk measures are obtained using equation (14).

\section{Multiple horizon}

Since now we have focused primarily on the 1-step forecast, but according to the regulatory rules and the Basel principles, it is necessary to make predictions for longer horizon (typically for 10-day ahead prediction). If we assume that the losses $\left(Z_{i}\right)$ are independent and are normally distributed, we obtain the popular square root of time rule. Similar statement can be generalized for larger family of distributions.

Let assume that $\left(Z_{i}\right)$ are iid and $k$ is the future time horizon. Then for strictly stable distributions with condition $Z_{1}+\ldots+Z_{1}^{d}=k^{1 / \alpha} \cdot X_{1}$, for some $\alpha \in(0,2]$ we obtain following equation:

$$
\begin{aligned}
& \operatorname{VaR}_{\alpha}(k)=k^{1 / \alpha} \cdot \operatorname{VaR}_{\alpha} . \\
& \operatorname{ES}_{\alpha}(k)=k^{1 / \alpha} \cdot E S_{\alpha} .
\end{aligned}
$$

However this rule doesn't hold perfectly for our model (2), because the parameter $1 / \alpha$ depends somehow on the underlying volatility of losses, for more details consult McNeil and Frey (2000). That is why there is opening a new area of interest, which is worth studying in more details and could bring more accurate estimates for dynamic risk measures in multiple horizon. 


\section{Summary}

In our study we have introduced a progressive methodology for measuring risk in finance. Since we have described only theoretical aspects, we would like to refer interested reader to all cited publications, where the extensive real case studies can be found. The applications of dynamic risk measures are more or less connected with market risk, because the underlying models need to work with the high-frequency data. Such demand on the type of data can be satisfied mostly in the market risk area and the applications in the area of credit and operational risk would be at least difficult if not impossible.

Both proposed dynamic risk measures in almost cases outperform the standard approaches, including some famous commercial products. For more details, see McNeil A.J., Frey R. (2000). If we take into account the possibility of the decomposition of the problem into two separate parts (EVT and ARMA-GARCH modeling), the practical implementation should be relatively quick and easy.

\section{References}

[1] McNEIL, A. J. - FREY R. (2000): Estimation of tail-related risk measures for heteroscedastic time series: an extreme value approach. Zürich, ETH, 2000.

[2] McNEIL, A. J. (1998): Calculating quantile risk measures for financial return series using Extreme Value Theory. Working paper, Zürich, ETH, 1998.

[3] EMBRECHTS, P. - KLÜPPELBERG, C. - MIKOSCH, T. (1997): Modelling extremal events for insurance and finance. Berlin, Springer-Verlag, 1997.

[4] VANÍČEK, K. (2003): Využití extreme value theory př́ ř́zení tržních rizik (Diploma work), Praha, MFF UK, 2003. 


\title{
Rizikové míry a dynamické systémy
}

\section{Karel Vaníček}

\begin{abstract}
Abstrakt
Článek se zabývá problematikou dynamických rizikových měr, konkrétně odhadem dynamického VaR a dynamického ES. Po obecném úvodu do problematiky rúzení rizik popisujeme v naší práci metody, které jsou klíčové pro samotný výpočetní a odhadovací postup. Nejprve je čtenářům popsána metoda ARMA-GARCH modelů z oboru časových řad a jsou komentovány předpoklady modelu, které se ukazují v praxi jako nereálné. Díky této skutečnosti je navrženo použití metodologie EVT, konkrétně metoda POT. Model POT je schopen aproximovat odlehlé konce námi pozorovaného rozdělení, což je zásadní vlastnost pro odhadování kvantilových rizikových měr. $\mathrm{V}$ předposledním odstavci je prezentován přímý výpočet odhadovaných rizikových měr. Poslední odstavec se zabývá některými nedostatky diskutovaných rizikových měr pro delší předpovědní období a také dává podněty pro další výzkumnou činnost této problematiky.
\end{abstract}

Klíčová slova: GARCH; EVT; VaR; ES.

\section{Risk Measures and Dynamical Systems}

\begin{abstract}
The paper is concerned with the dynamic risk measures, e.g. with the estimation of the dynamic VaR and the dynamic ES. After general introduction into the problematic of risk management we describe the methods that are essential for the whole estimation and computation process. At first we introduce very popular time series ARMA-GARCH models and also comment the assumptions of the model that seems to be unrealistic. Due to this fact we introduce EVT models, specifically the POT model. The POT model is able to approximate the far ends of distribution, which are crucial for the estimation equation of quantile based measures. In the last but not least paragraph there is direct estimation of both the dynamic VaR and the dynamic ES. In the last paragraph we discuss possible shortcomings of the proposed model for longer time horizon of prediction and the topic for possible research is indicated.
\end{abstract}

Key words: GARCH; EVT; VaR; ES.

JEL classification: G30 